\title{
Áttekintés a vezetői információs rendszerek magyar felsőoktatásban való megjelenéséről a Debreceni Egyetem példáján keresztül
}

Overview of the Appearance of Management Information Systems In Hungarian Higher Education through the Example of the University of Debrecen

\author{
Sz. VINCZE, T. GEBEI \\ Debreceni Egyetem, Kancellária, VIR Központ, vincze@fin.unideb.hu \\ Debreceni Egyetem, Kancellária, VIR Központ, gebei.timea@fin.unideb.hu
}

Absztrakt. Az elmúlt években a magyar felsőoktatásban az egyre csökkenő hallgatói létszám komoly versenyhelyzetet teremtett az intézmények között, amelyben már nemcsak a hazai, hanem a külföldi egyetemek is versenytársnak bizonyulnak. Ahhoz, hogy a hazai intézmények ebben a versenyben megfelelő mértékben helyt tudjanak állni, a vezetőket olyan megfelelően strukturált, naprakész információval szükséges ellátni, amelyek képesek támogatni a döntéshozatalt. A Debreceni Egyetemen sikeresen adaptált vezetối információs rendszer évek óta müködik és az adatszolgáltatásokban, ad hoc jelentésekben jelentôs támogatást nyújt, azonban még sok területen van előre lépési lehetôség. A tanulmány a Debreceni Egyetem példáján keresztül a vezetối információs rendszerek fontosságára hívja fel a figyelmet.

Abstract. In recent years, the ever-decreasing number of students in Hungarian higher education has created a serious competition between institutions, in which not only national but also foreign universities prove to be competitive. In order for national institutions to be able to compete adequately in this competition, managers need to be provided with well-structured, up-to-date information that can support decision-making. The management information system, which successfully adapted at the University of Debrecen, has been in operation for years and provides significant support in data reporting and ad hoc reporting, but there are still many opportunities for advancement. The study draws attention to the importance of management information systems through the example of the University of Debrecen.

\section{Bevezetés}

A vezetői információs rendszerekkel (VIR) hosszú éveken keresztül elsősorban a versenyszférában találkozhattunk. Segítségükkel növekedett a vállalati hatékonyság, gyorsult és könnyebbé vált az operatív munkavégzés, így egyre több vállalat adaptált különböző ERP rendszereket. A versenyszférában - nevéből eredően is - a legfontosabb a versenyelőny megszerzése, amihez a vezetői 
információs rendszerek komoly segítséget nyújthatnak. Ezen rendszereket a magánszektor sikeresen elfogadta, az eredmények közvetlen gyakorlati jelentőséggel bírnak (Wowczko, 2013). Általánosságban nézve, a közszféra több éves lemaradással követi a versenyszféra változásait, így várható volt a vezetői információs rendszerek megjelenése a közintézményekben is. Az egyre nagyobb számú felhasználó és a rendszerek bevezetési költségeinek csökkenése elhozta a közszféra számára is a változást, itt is hangsúlyos szerepet kaptak a vállalati szektorban már bevezetett és onnan átvételre javasolt vezetési-szervezési technikák (Turcsányi, 2008). Működésüket tekintve hasonló adatok tárolhatók a köz- és a versenyszféra szereplőiről, a már használt technológia alkalmazható közcélokra is, azonban az egyes szereplők feladatait és a gazdálkodási környezeteit tekintve nagyon nagy az eltérés.

A közszféra számára közpénzek finanszírozásával egy közfeladat elvégzése a legfőbb cél, míg a versenyszféra a lehető legnagyobb nyereségszint elérésére törekszik a lehető legalacsonyabb költségszint fenntartása mellett. A közszféra szereplői mindezt a tevékenységet a nyilvánosság előtt teszik, tevékenységüknek átláthatónak kell lennie, hiszen a köz érdekében a köz pénzéből végzik feladatukat, míg a vállalatok tulajdonosaiknak tartoznak elszámolással. A nyilvánosság előtt működő szervezetek stratégiai döntéseik meghozatalában korlátok közé szorulnak (Nutt, 2006).

Ugyanakkor a közszférában is szükséges gazdálkodni és megfelelő döntéseket hozni, ami csak megfelelő információ-áramlás mellett biztosítható. A közszféra fő célja, hogy kormányzati szolgáltatásokat nyújtson a társadalomnak megfelelő időben és meghatározott költségvetésből. Ezeknek az elvárásoknak megfelelni folyamatos döntéshozatallal lehetséges (Wowczko, 2013).

\section{A felsőoktatás információs igényei}

Az elmúlt évek a magyar felsőoktatási intézményeknek komoly változásokat hoztak. 2010/2011. tanévhez képest 2017/2018. tanévben közel 39000 hallgatóval kevesebb tanult nappali képzésben (KSH, 2018). Ez egyrészt köszönhető a demográfiai változásoknak, másrészt azonban szemtanúi lehetünk annak a kivándorlási hullámnak, ami a KSH elemzése szerint elsősorban a magasabban képzett munkavállalókra jellemző, köztük a fiatalokra (KSH, 2014).

Ennek következménye, hogy a magyar felsőoktatási intézmények már nemcsak egymással, hanem a külföldi intézményekkel is versenyben vannak. Ezért rákényszerülnek, hogy olyan lépéseket tegyenek, amelyek révén jobbak, kelendőbbek lesznek a felsőoktatási piacon, amelyeknek eredményeként a leendő hallgatók mégis inkább itthon válogatnak az intézmények között és nem külföldön.

Jelenleg az egyetemek egy versengő környezetben kell működniük. Ezért ma már a felsőoktatási intézményekre is úgy kell tekinteni, mint egy olyan szervezetre, ami szolgáltatást nyújt a vevőinek. Ha sikeresen akarunk vezetni egy ilyen szervezetet, akkor szükséges ezt következetesen, átlátható módon irányítani (Farana - Hutyra, 2007).

Ahhoz azonban, hogy a hazai intézmények a külföldi egyetemekkel versenyben maradjanak, pontosan ismerni kell, hogy a hallgatók milyen szempontok alapján választanak felsőoktatási intézményt. Ezen szempontok alapján azonosítani szükséges az előrehaladást mérni képes mutatószámokat. A 
mutatószámok folyamatos monitorozásával juthatunk azon információkhoz, hogy hol vannak a beavatkozási pontok, hol szükséges elsősorban kezdeményezni a fejlődést.

Sokféle módon mérik a felsőoktatási intézmények teljesítményét, ami a nemzetközi rangsorokban is megnyilvánul. Kevésbé valószínű azonban, hogy a leendő hallgatók a nemzetközi rangsorokat nézegetve válogatnak és hoznak döntést továbbtanulásukról.

A Fulbright Bizottság definiált nyolc tényezőt, amit az amerikai fiatalok figyelmébe ajánlanak, hogy segítsen eldönteni, mely felsőoktatási intézményt válasszák. Ezek alapján könnyebben tudnak döntést hozni, hogy melyik egyetem képzése illeszkedik a legjobban az elképzeléseikhez.
1) a sikeres felvételi követelményekhez elvárt minimális tudás,
2) a szakosodás lehetősége, választéka,
3) a campus földrajzi elhelyezkedése, mérete, felszereltsége,
4) az egyetemi élet,
5) a szak versenyképessége,
6) a részvétel költségei, a finanszírozás lehetőségei,
7) a szak akkreditációja és hírneve,
8) a fejlettség állapota (Fulbright Commission, 2012).

Ezek a tényezők könnyen mérhetővé tehetők, az adatok nagy része rendelkezésre áll egy felsőoktatási intézményben: a felvételi ponthatárok adatai, a szakok kínálata országosan megtekinthetők, mérhető a hallgatói lemorzsolódás, a képzési időn túl végzettek aránya, a hallgatói elégedettség, a végzettek mennyi idő alatt tudnak munkába állni, milyen kezdőfizetéssel, a hallgatók oktatásra fordított költségei meghatározhatók. Ezen adatok gyűjtése, strukturált és idősoros tárolása, lekérdezése azonban nehézségekbe ütközhet megfelelő információs rendszer használata nélkül.

\section{Vezetői információs rendszerek a hazai felsőoktatásban}

A magyarországi felsőoktatásban európai uniós források bevonásával 2009-ben vették kezdetüket az adattárház alapú VIR bevezetési projektek. Az újítás lehetővé teszi, hogy az intézmények vezetési modelljei közelítsenek egymáshoz, azaz lehetőség nyílik némiképp az egységesítésre. Ezek a rendszerek lehetőséget teremtenek arra, hogy az egyetemek kielégítsék döntéstámogatási igényeiket, illetve teljesítsék adatszolgáltatási kötelezettségeiket az őket felügyelő szervezetek felé. A rendszer működése során előállítja a legfontosabb mutatószámokat, mindemellett lehetőséget biztosít, hogy megfelelő informatikai tudással rendelkező végfelhasználók új mutatószámokat, jelentéseket készítsenek. Egy fejlett webes felület, portál segítségével pedig lehetséges az információk hatékony megosztása, a riportok és a kinyert adatok tárolása (Bálint-Halász, 2011).

A projekt hangsúlyozta, hogy az egyetemeken szükséges olyan szervezet létrehozása, amelyik a vezetői információs rendszer müködtetésével, kezelésével, a beérkező adatok tisztaságával, riportok, jelentések készítésével foglalkozik. A fejlesztések első fázisában a cél a felsővezetés információs igényeinek kielégítése volt, a későbbi bővítés lehetőségeit fenntartva. A VIR-re vonatkozóan a következő célok kerültek meghatározásra: az információkat az intézmény döntéshozó szervei és az intézményi, szakmai vezetés számára elérhetővé kell tenni; vizsgálni kell az egyetem gazdasági 
körülményeit és az egyetemi vezetési struktúrát; a mérések kialakításához minél szélesebb körben kerüljenek bevonásra a vezetők; teremtsék meg a feltételeit, hogy a rugalmasan tudjon a rendszer reagálni a változásokra (DE, 2016).

A VIR rendszer az intézményben meglevő forrásrendszerek (információs rendszerek) adataira építkezve biztosítja az intézményen belül fellelhető adatok könnyű, gyors és rendszerezett elérését, valamint ennek az intézményi folyamatokban történő hasznosulását. Az intézményben múködő VIR rendszer segítségével - a minőségirányítás rendszerével együtt - a felsőoktatási intézmény vezetése hozzájuthat ahhoz a szükséges és elégséges információhoz, amely a hatékony vezetéshez elengedhetetlen.

A hazai felsőoktatási intézmények monitoring funkciója a különböző szintű szervezeti célok megvalósításának folyamatát hivatott figyelemmel kísérni, melynek során a releváns eseményekről és tevékenységekről rendszeresen, strukturált, döntéstámogató információkhoz juttatja az intézmény vezetőit az Intézményfejlesztési tervben és egyéb dokumentumokban megfogalmazott célok elérésének szolgálatában álló szabályzatokban, folyamatleírásokban, eljárásrendekben foglalt követelmények végrehajtásához (DE, 2016)

A felsőoktatási intézmények esetében is a gyors és biztonságos működéshez elengedhetetlen egy jól múködő információs háttér kialakítása (Lábas - Bács, 2015).

\section{Vezetői információs rendszer a Debreceni Egyetemen}

\subsection{Debreceni Egyetem iránti hallgatói kereslet}

Az ország és az Észak-alföldi régió demográfiai helyzete jelentős befolyással van a Debreceni Egyetem képzési alaptevékenységének keresletére. A lakosság 14,9\%-a, közel 1,5 millió ember él a térségben, 588 ezer háztartást alkotva. A háztartások átlagos taglétszáma magasabb (2,5 fő/háztartás), mint az országos átlag (2,4 fő/háztartás). A demográfiai folyamatok az országos trendekhez hasonlóan alakulnak: bár az Észak-Alföld régió a második legnagyobb régió, de folyamatosan csökkenő népesség jellemzi (15 év alatt a lakosságszám csaknem 5,4\%-kal csökkent). Térséget is érinti az utóbbi időszakot jellemző kivándorlási hajlandóság. Ez a folyamat az elkövetkező évtizedek népesedési és gazdasági viszonyaira komoly kihatással lehet. A hazai mobilitási és demográfiai trendeket figyelembe véve a felsőoktatásba jelentkezők számának további csökkenése várható (DE IFT, 2016).

Ezen változások hatása a Debreceni Egyetem hallgatói létszámadatainak csökkenésében is megjelenik, amit az 1. ábra mutat be. Öt tanév alatt közel 11\%-os csökkenés következett be a hallgatói létszámadatokban. 


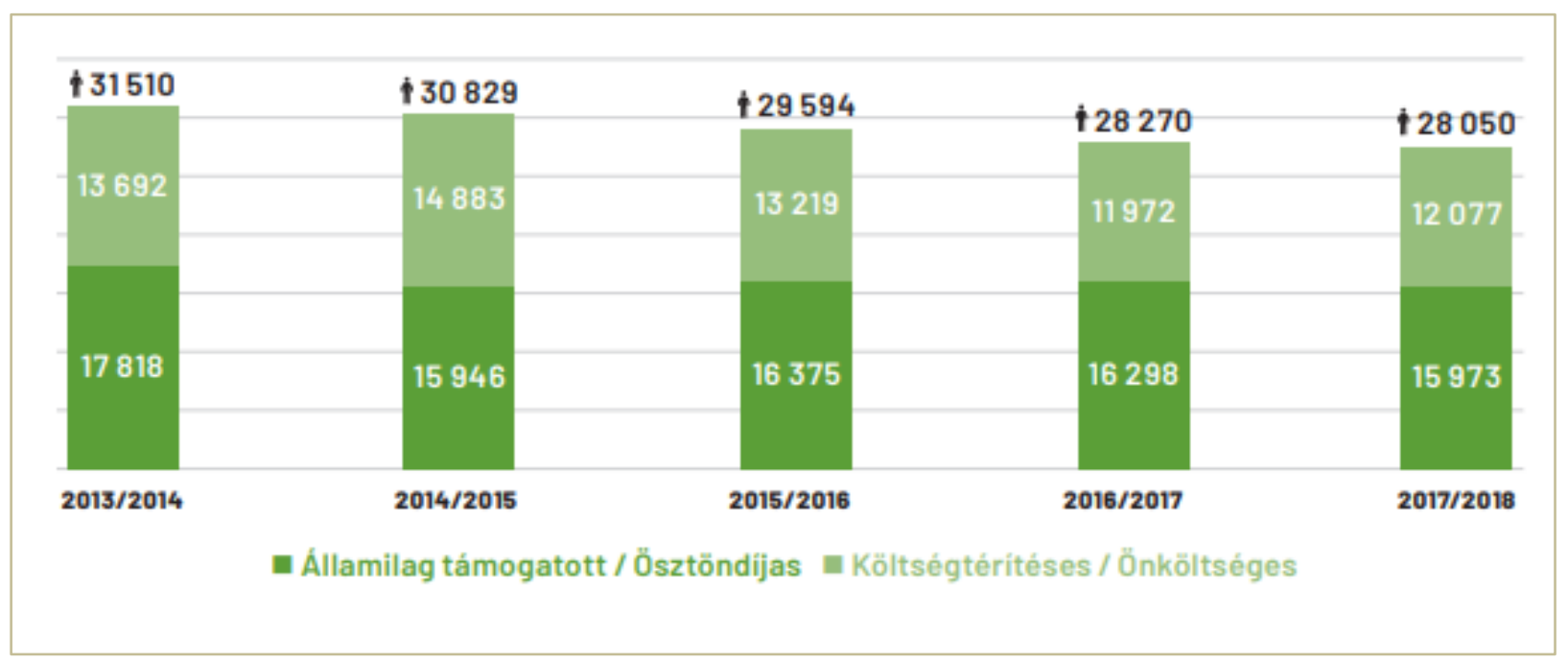

1. ábra: A DE hallgatói létszámadat finanszírozási forma szerint. 2013-2018 (DE, 2018)

\subsection{Vezetői információs rendszer bevezetése a Debreceni Egyetemen}

A Debreceni Egyetemen a VIR rendszer kialakításának elsődleges célja az volt, hogy az intézményben meglévő forrásrendszerek adataira építkezve egy olyan vezetői információs rendszer jöjjön létre, amely biztosítja az intézményen belül a fellelhető validált adatok könnyü, gyors és rendszerezett elérését, lekérdező és riport-generáló képessége révén információt nyújt a különböző szempontú vizsgálatokhoz, ezáltal megalapozza a vezetői döntéseket, és eszközt biztosít a minisztériumok és egyéb más intézmények felé a szükséges, időben történő információ-szolgáltatáshoz.

A VIR-nek az intézményi folyamatokba való beépülésével:

- létrejönnek a korábbinál sokrétűbb, differenciáltabb információk elérésének és hasznosításának feltételei,

- megvalósul az összegyűjtött információk egyszerű újrafelhasználásának lehetősége (pl. pályázatok készítésekor),

- lehetővé válik az intézményi igazgatási erőforrások hatékonyabb felhasználása, az automatizációt kihasználva jelentősen csökkenthető az adatszolgáltatással kapcsolatos munkaterhelés, egyszerübb és könnyebb lesz az intézményi adatszolgáltatás az ágazati irányítás felé,

- lehetőség nyílik benchmarkok készítésére, az Egyetem összemérheti magát más felsőoktatási intézményekkel,

- naprakészen követhetővé válnak a DE (stratégiai) céljai és az ezek elérését támogató folyamatok,

- az Egyetem vezetői gyorsan hozzájuthatnak az Egyetem ellenőrzött adataihoz, és a korábbinál jobban megalapozhatják döntéseiket.

A Debreceni Egyetem VIR felépítését az 2. ábra mutatja be. 


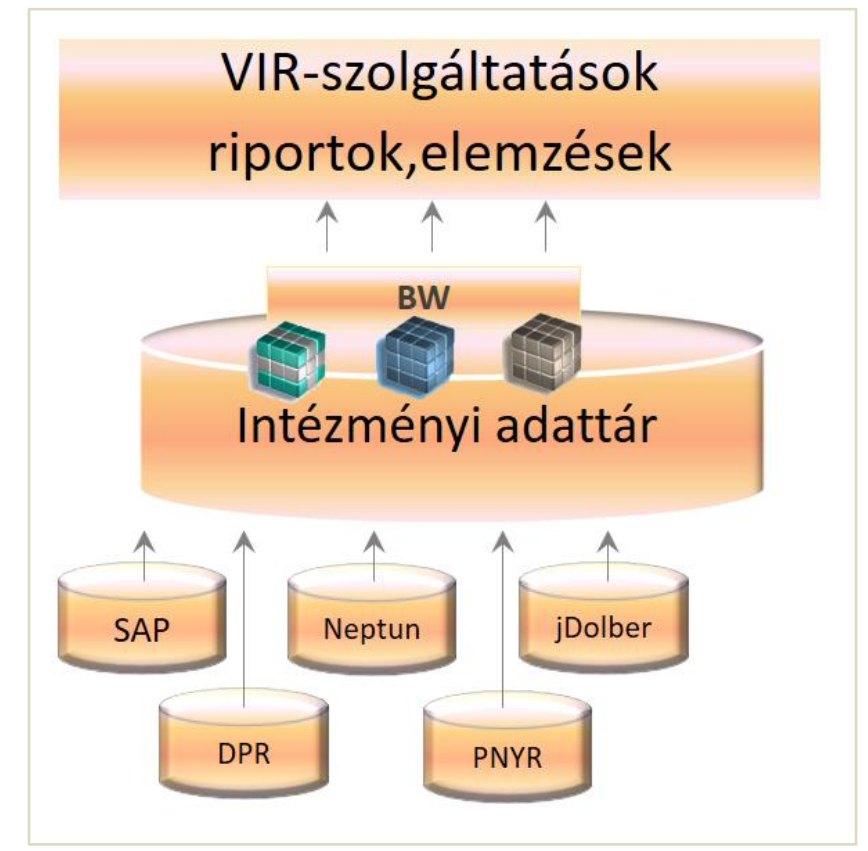

2. ábra: A Debreceni Egyetem VIR sematikus szerkezete (IFUA, 2009)

A forrásrendszerek a következők:

- SAP: a gazdaságadminisztrációs modul, ez a felelős többek között pl. a pénzügyi adatokért,

- DPR: a diplomás pályakövető rendszer,

- Neptun: a hallgatói adatbázis,

- PNYR: a pályázati nyilvántartó rendszer,

- jDolBer: a munkaügyi adatokat tartalmazó adatbázis.

A VIR-ben előállított riportok három különböző kategóriába sorolhatók: stratégiai riportok, folyamati beszámolók, vagy szakterületi beszámolók. A 3. ábrán látható a riportok hierarchiája és a folyamatok iránya.

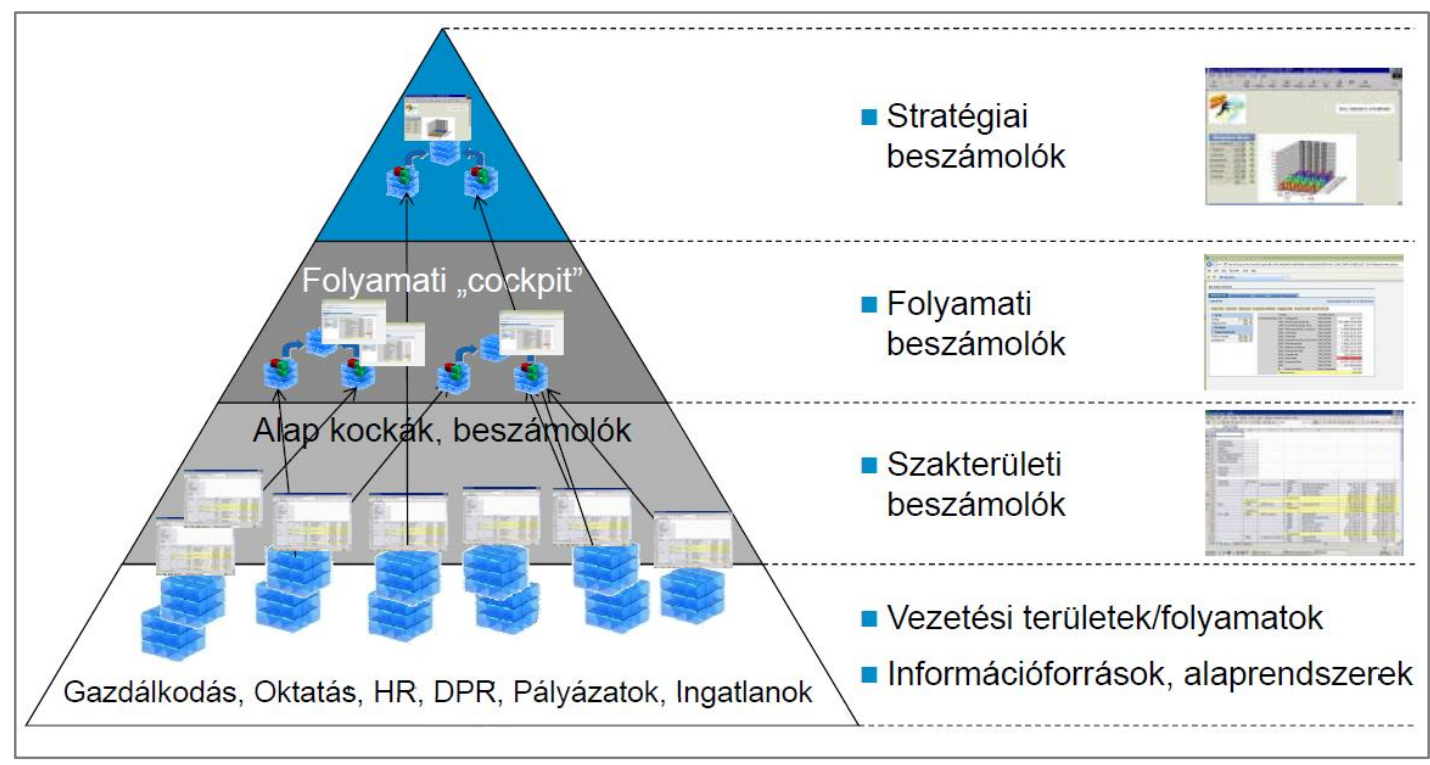

3. ábra: DE VIR riportok hierarchiája (IFUA, 2009) 
A stratégiai beszámolók elsősorban a felsővezetés információs igényeinek kielégítésére szolgálhatnak. Jellemzően összeegyetemi adatokat tartalmaznak minden forrásrendszer vonatkozásában. A folyamati beszámolók kialakításával alap- és főfolyamatok, támogató folyamatok mérése valósul meg. A folyamati beszámolókban különböző forrásrendszerek adatai jelennek meg egy riportban. A szakterületi beszámolók az egyes szakterületekre önálló riportok kialakítását jelentik, melyek jellemzően középvezetőknek készülnek és egy riport alapvetően egy forrásrendszerhez köthető.

Az egyetemi VIR bevezetésének első szakasza (DE VIR1 projekt) az adattárház kialakítására, implementálására, valamint a mutatószámrendszer kialakítására, a vezetői mutatószámok definiálására és riportok készítésére irányult. A második fázisban (DE VIR2 projekt) a folyamatok további harmonizálása, új adatkörök VIR-be való becsatornázása (MTMT) és a rendszer működéséhez, működtetéséhez kapcsolódó finomhangolások kerültek a fejlesztések középpontjába.

A riportok eredményeinek felhasználásával hatékonyabbá válhat a stratégiai és az operatív szintű döntéshozatal. A stratégiai riportokat elsősorban az Intézmény Fejlesztési Tervhez kapcsolódóan lehet definiálni, az intézmény stratégiai céljaival összefüggésben. Operatív szinten azt szükséges megvizsgálni, hogy milyen aktuális nehézségekkel küzdenek az egyes szervezetek és ezekhez az igényekhez szükséges igazítani a riportokat.

\section{A vezetői információs rendszerek kialakításának, működésének nehézségei, lehetőségei a felsőoktatásban}

A felsőoktatási intézmények különböző tevékenységeihez kapcsolódó információs rendszerek általában nem integráltan működnek, minimális szinten kommunikálnak egymással. Könnyen előfordulhat, hogy ugyanazon adat többszörösen kerül tárolásra a különböző rendszerekben, amiknek összeegyeztetése szinte lehetetlenné válik. Ráadásul ezeknek a rendszereknek számos felhasználója van, akik különböző elvek és szabályzatok mentén rögzítik az adatokat. Ilyen feltételek mellett nagyon nehéz a forrásrendszerekben elérni az adattisztaságot, illetve integrált múködést biztosítani a vezetői információs rendszerekben. Egy jól működő VIR alapfeltétele, hogy a különböző adatbázisokat összehangoljuk, ugyanazon objektumok azonos néven legyenek szólítva, a törzsadatok egy helyen legyenek tárolva.

Amennyiben a vezetői információs rendszerek input-jai megfelelőek, ezt követően van lehetőség az output-ok, a riportok definiálására. Ehhez elengedhetetlen a vezetés elhivatottsága, az ő igényeik mentén kell ugyanis meghatározni a szükséges adatköröket, amikből kiindulva épülhetnek fel a megfelelően riportolható adatmodellek. A riportok elkészítéséhez hozzátartozik az is, hogy az egyes alapfogalmakat újra kell gondolni, szükség esetén újra kell definiálni, hogy mindenki, aki értelmezi majd az adatokat, ugyanazt értse alattuk. A riportok megjelenítésének kialakítása is komoly kihívás, melyre úgy kell tekinteni, mint egyfajta marketing tevékenységre, ami tovább növeli a VIR kialakításának erőforrás-igényét.

Ezeknek a feladatoknak az elvégzése után szükséges kialakítani a müködtetésre vonatkozó szabályokat, kijelölni a forrásrendszer és a VIR oldali felelősöket. Definiálni szükséges, hogy mely forrásrendszerekből milyen gyakorisággal érkezzenek az adatok, az adattöltési folyamatokat kik 
monitorozák. Meg kell határozni a különböző jogosultsági szinteket és hozzájuk kell rendelni az egyes felhasználókat, hogy mely riportok mely szinteken elérhetők.

A rendszer bevezetése és a működtetés feltételeinek kialakítása ugyan egy egyszeri, de rendkívül összetett feladat, mely rengeteg buktatót rejt, és erőforrás-igénye hatalmas terhet ró egy-egy intézményre.

Ugyanakkor egyértelműen érvényesíthető volna a költség-haszon elv, hiszen a VIR felhasználási lehetőségeinek tárháza végtelen, bár ezt az intézmények ma még kevésbé tudják kiaknázni.

A Debreceni Egyetem jelenleg jellemzően ad hoc kimutatások és adatszolgáltatások elkészítésére használja a rendszert, illetve az intézmény disszeminációs tevékenységét támogatva népszerűsító kiadványok készítéséhez szolgáltat adatokat.

A VIR lehetséges felhasználási területeit mutatja be a 4. ábra.

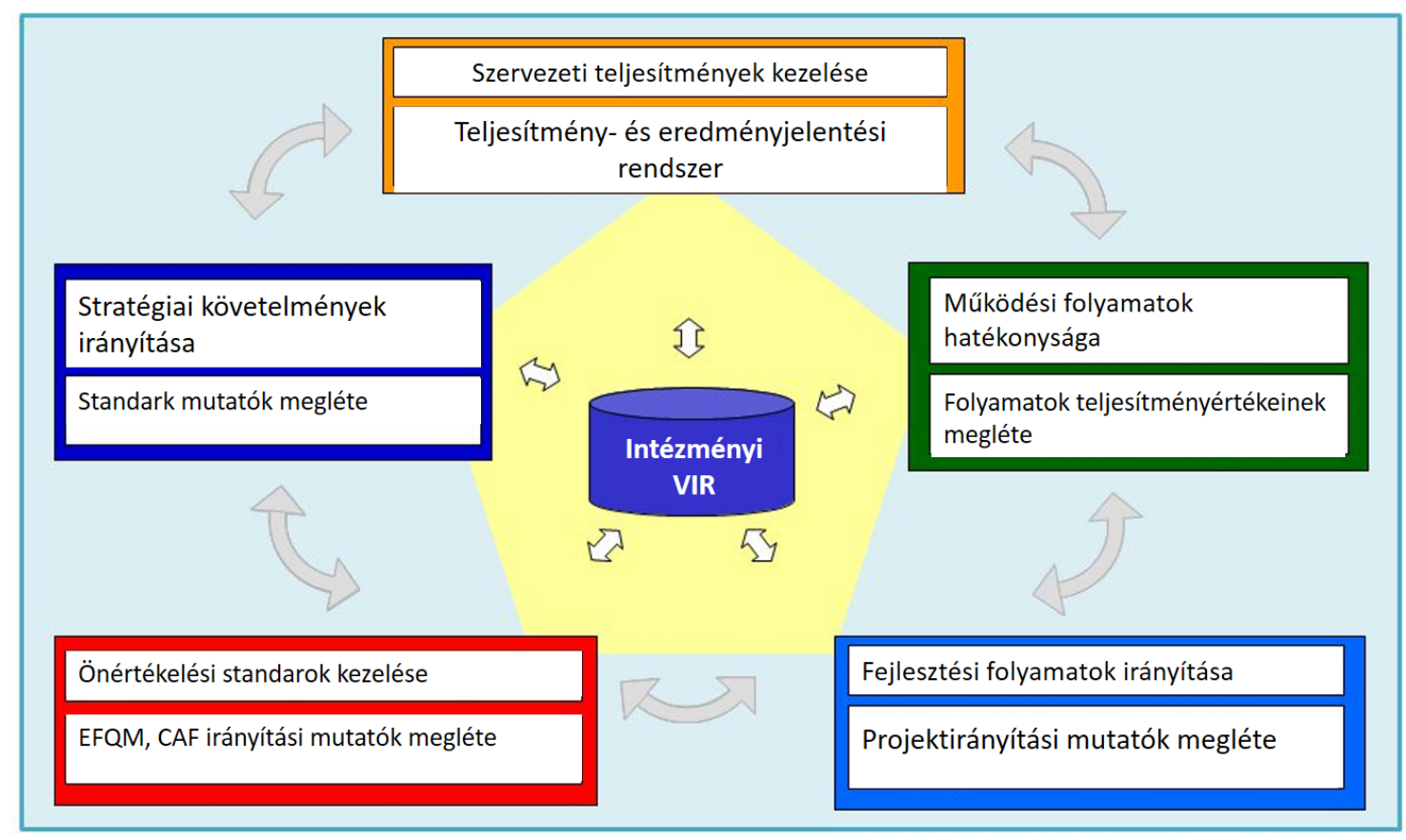

4. ábra: A felsőoktatási VIR felhasználási területei, (Bángi-Magyar, 2010)

A VIR-nek számos lehetséges felhasználási területe létezik, amelyek jelenleg részben vannak csak kihasználva, mint például az oktatói-kutatói teljesítmény értékelés mutatószámainak monitorozása, illetve költségvetési tervezési folyamatokba való bekapcsolása.

\section{Összefoglalás}

A vezetői információs rendszerek a vállalati szférából emelkedtek ki, és miután a magánszektorban bebizonyosodott, hogy hatalmas előnyhöz juttatják az azokat használó piaci szereplőket, térhódításuk elindult a közszférában is. A magyar felsőoktatásban végbemenő demográfiai folyamatok, mint a hallgatók csökkenése és a fiatalok körében a kivándorlási hajlandóság növekedése, felerősítették a versenyhelyzetet az intézmények között. Ez az erősödő versenyhelyzet pedig a felsőoktatásban is 
egyre inkább megköveteli a vezetőktől, hogy naprakész információk birtokában hozzák meg döntéseiket, hogy hallgatói létszámukat próbálják megtartani, annak csökkenési folyamatát lassítani. A magyar felsőoktatásban 2009-ben indultak a VIR implementálását célzó projektek, azzal a céllal, hogy az intézmények különböző tevékenységi területekhez kapcsolódó hatékonyságát növeljék. A Debreceni Egyetemen is megvalósult a VIR bevezetése, a fejlesztése két ütemben történt, öt forrásrendszer becsatornázásával. Kialakításra került egy stratégiai mutatószámrendszer, illetve három szinten készültek riportok a vezetés számára. Annak ellenére, hogy a Debreceni Egyetemen sikeresnek tekinthető a VIR projekt, a rendszer használata jelenleg ad hoc jelentések és adatszolgáltatások elkészítésére korlátozódik, pedig a VIR-ben nagyon sok lehetőség van, amelyek kiaknázása a jövő feladata.

\section{Hivatkozások}

[1] Központi Statisztikai Hivatal (2018) Statisztikai tükör, Oktatási adatok, 2017/2018.

[2] Debreceni Egyetem (2018) MinDEN a számok tükrében

[3] Debreceni Egyetem (2017) A Debreceni Egyetem Intézményfejlesztési Terve

[4] Debreceni Egyetem (2016) VIR Központ múködési rend

[5] I. Lábas - Z. Bács (2015) Management Control System in the University of Debrecen. Procedia Economics and Finance. 32 pp. 408-415.

[6] Központi Statisztikai Hivatal (2014) A SEEMIG - Managing Migration in South East Europe transznacionális együttmúködési projekt „Helyzetkép a magyarországi elvándorlásról” sajtóanyag

[7] I. A. Wowczko (2013) The Use of BI in Government Driven Environment. Business Intelligence and Data Mining. 9. pp. 1107-1111.

[8] J. Bálint - G. Halász (2011) Vezetôi döntéshozatal és felsőoktatási menedzsment. pp. 25-49. In: AVIR Kézikönyv. (Szerk. Bángi-Magyar A.-Farkas K.-Horváth T.-Kiss L.). Educatio Társadalmi Szolgáltató Nonprofit Kft., 293 p. ISBN 978-963-9795-45-7

[9] Fulbright Commission - Factors to Consider <http://www.fulbright.org.uk/study-in-the-usa/undergraduate-study/choosinguniversities/factors-to-consider> , letöltés dátuma: 2019.05.02

[10] A. Bángi-Magyar et al. (2010) AVIR kézikönyv: stratégiaalkotás, VIR, stratégia mutató, adattár, felsőoktatási menedzsment. Educatio Társadalmi Szolgáltató Nonprofit Kft. Budapest. pp. 126. ISBN: 978-963-9795-45-7

[11] IFUA Horváth \& Partners Kft. (2009) Projektdokumentáció

[12] K. Turcsányi (2008) Menedzsment-trendek a közszférában. MEB 2008 - 6th International Conference on Management, Enterprise and Benchmarking, Budapest, May 30-21. pp. 335-342.

[13] R. Farana - M. Hutyra (2007) The Way from Quality System to Excellence in Higher Education. 51st EOQ Congress, Prague, 22-23 May.

[14] P. Nutt (2006) Comparing public and private sector decision-making practices. Journal of Public Administration Research and Theory. 16 (2) pp. 289-318. 